\title{
Tetrandrine suppresses pro-inflammatory mediators in PMA plus A23187-induced HMC-1 cells
}

\author{
OK-HWA KANG ${ }^{1}$, HYEON-JIN AN $^{1}$, SUNG-BAE KIM ${ }^{2}$, SU-HYUN MUN ${ }^{2}$, YUN-SOO SEO $^{1}$, \\ DAE-KI JOUNG ${ }^{1}$, JANG-GI CHOI ${ }^{1}$, DONG-WON SHIN ${ }^{3}$ and DONG-YEUL KWON ${ }^{1}$ \\ ${ }^{1}$ Department of Oriental Pharmacy, College of Pharmacy, Wonkwang University, Wonkwang Oriental Medicines \\ Research Institute; ${ }^{2}$ BK21 Plus Team, Professional Graduate School of Oriental Medicine, \\ Wonkwang University, Iksan, Jeonbuk 540-749; ${ }^{3}$ Department of Oriental Medicine Resources, \\ Sunchon National University, Sunchon, Jeonnam 540-742, Republic of Korea
}

Received November 4, 2013; Accepted February 27, 2014

DOI: $10.3892 /$ ijmm.2014.1683

\begin{abstract}
Tetrandrine (TET), a bis-benzylisoquinoline alkaloid from the root of Stephania tetrandra, is known to possess antitumor activity in various malignant neoplasms. However, the precise mechanism of TET-mediated immune modulation remains to be clarified. One of the possible mechanisms for its protective properties is by downregulation of the inflammatory responses. In the present study, the human mast cell line (HMC-1) was used to investigate this effect. TET significantly inhibited the induction of inflammatory cytokines such as tumor necrosis factor (TNF)- $\alpha$, interleukin (IL)-6, and IL- 8 by phorbol 12-myristate 13-acetate (PMA) plus A23187. Moreover, TET attenuated expression of cyclooxygenase (COX)-2. In activated HMC-1 cells, the phosphorylation of extra-signal response kinase (ERK1/2) and c-jun N-terminal Kinase (JNK1/2), but not p38 mitogen-activated protein kinase, was decreased by treatment of the cells with TET. TET inhibited PMA plus A23187-induced nuclear factor (NF)- $\kappa \mathrm{B}$ activation, I $\mathrm{B}$ degradation and phosphorylation. Furthermore, TET suppressed the expression of TNF- $\alpha$, IL-8, IL-6 and COX-2 through suppression of the ERK1/2, JNK1/2, $\mathrm{I} \kappa \mathrm{B} \alpha$ degradation and phosphorylation, and NF- $\kappa \mathrm{B}$ activation. These results indicated that TET exerted a regulatory effect on inflammatory reactions mediated by mast cells.
\end{abstract}

\section{Introduction}

Tetrandrine (International Union of Pure and Applied Chemistry name: 6, 6', 7, 12-tetramethoxy-2, 2'-dimethyl-1 $\beta$-berbaman; Chemical Abstracts Service no. 518-34-3; $\mathrm{C}_{38} \mathrm{H}_{42} \mathrm{~N}_{2} \mathrm{O}_{6}$;

Correspondence to: Dr Dong-Yeul Kwon, Department of Oriental Pharmacy, College of Pharmacy, Wonkwang University, 344-2 Sinyong-dong, Iksan, Jeonbuk 570-749, Republic of Korea

E-mail: sssimi@wonkwang.ac.kr

Key words: tetrandrin, pro-inflammatory mediator, human mast cell molecular weight, 622.74988; TET; molecular structure of TET shown in Fig. 1) is a bis-benzylisoquinoline alkaloid from the root of Stephania tetrandra that has been used in China for several decades for the treatment of arthritis, arrhythmia, inflammation and silicosis (1). TET has been shown to exhibit antifibrotic activity in silicosis (2,3). Early findings showed that TET may be useful in the therapy of chronic inflammatory diseases in which IL-1 or TNF play a role in pathogenesis $(4,5)$. TET was reported to inhibit cell proliferation in various types of cancer cells (6). However, the anti-inflammatory effects of TET on mast cell-mediated anti-inflammation and cell regulation have not yet been reported.

Inflammation is part of the complex biological response of vascular tissues to harmful stimuli, such as pathogens, damaged cells, or irritants (7). Mast cells are one of the major effector cells in the immune response system, which respond to the danger signals of innate and acquired immunity with immediate and delayed releases of inflammatory mediators. In allergic inflammation, humans produce immunoglobulin $\mathrm{E}(\mathrm{IgE})$ against allergen infiltration resulting in the activation of mast cells which release histamine, tumor necrosis factor- $\alpha$ (TNF- $\alpha$ ), interleukin (IL)-6, IL-8, and NF- $\kappa \mathrm{B}$ (8). The results of those studies demonstrated that NF- $\kappa \mathrm{B}$ activation and the subsequent activation of pro-inflammatory cytokine gene expression are critically important in the initiation and perpetuation of allergic inflammation. Moreover, $\mathrm{NF}-\kappa \mathrm{B}$ activation was reported to be required for the expression of a number of inflammatory proteins such as GM-CSF, TNF- $\alpha$, IL-6, COX-2 and inducible nitric oxide synthase (iNOS) (9). Therefore, the inhibition of $\mathrm{NF}-\kappa \mathrm{B}$ was able to reduce the expression of inflammatory genes and it is a mechanism by which anti-inflammatory agents potentially elicit their anti-inflammatory effects (10).

Mitogen-activated protein kinases (MAPKs) belong to a large family of proline-directed serine/threonine protein kinases that play a fundamental role in cell functions. The activation of MAPK proceeds through a cascade of upstream molecules in an orderly manner. The inhibition of MAPK activity pharmacological or genetic approaches blocks allergic inflammation of airways. Specifically, ERK1/2 is important for mast cell differentiation/proliferation, survival and eicosanoid release (11-13). 
In the present study, we investigated the potential effects of TET on the production of inflammatory cytokines in the human mast cell line (HMC-1). Subsequently, the effects of TET were evaluated on PMA plus A23187-induced expression of pro-inflammatory mediators by inhibiting MAPK and $\mathrm{I} \kappa \mathrm{B} \alpha / \mathrm{NF}-\kappa \mathrm{B}$ signaling pathways.

\section{Materials and methods}

Reagents. Tetrandrine was purchased from Sigma-Aldrich and was dissolved in dimethyl sulfoxide (DMSO). The final DMSO concentration was adjusted to $<0.01 \%(\mathrm{v} / \mathrm{v})$ in the culture media. PMA, the calcium ionophore A23187 (Calcymycin; $\mathrm{C}_{29} \mathrm{H}_{37} \mathrm{~N}_{3} \mathrm{O}_{6}$ ), and 3-[4,5-dimetylthiazol-2-yl]2,5-diphenyltetrazolium bromide (MTT) were purchased from the Sigma Chemical Co. (St. Louis, MO, USA). Iscove's modified Dulbecco's medium (IMDM) was obtained from Gibco BRL (Grand Island, NY, USA). Anti-human TNF- $\alpha$, IL-6 and IL- 8 antibodies, biotinylated anti-human TNF- $\alpha$, IL- 6 and IL- 8 antibodies, and recombinant human TNF- $\alpha$, IL- 6 and IL-8 were purchased from BD PharMingen (San Diego, CA, USA). The COX-2, $\beta$-actin, NF- $\kappa$ B, pI $\kappa$ B, I $\kappa$ B and MAPKs (P-ERK1/2, P-JNK1/2, P-p38 MAPK, ERK1/2, JNK1/2, and p38 MAPK) antibodies were purchased from Santa Cruz Biotechnology, Inc. (Santa Cruz, CA, USA). SYBR Premix Ex Taq ${ }^{\mathrm{TM}}$ was purchased from Takara Bio, Inc. (Shiga, Japan).

Primer design. Sequences of oligonucleotide primers were designed for real-time PCR using Primer Express ${ }^{\circledR}$ software (Takara, Dalian, China) (Table I).

Cell culture. HMC-1 cells were cultured in IMDM and supplemented with $100 \mathrm{U} / \mathrm{ml}$ of penicillin, $100 \mu \mathrm{g} / \mathrm{ml}$ of streptomycin, and $10 \%$ fetal bovine serum (FBS) at $37^{\circ} \mathrm{C}$ in $5 \% \mathrm{CO}_{2}$ with $95 \%$ humidity. The HMC-1 cells were treated with TET (10-50 $\mu \mathrm{M})$ for $1 \mathrm{~h}$. The cells were then stimulated with $50 \mathrm{nM}$ of PMA plus $1 \mu \mathrm{M}$ of $\mathrm{A} 23187$ and incubated at $37^{\circ} \mathrm{C}$ for the indicated time periods (30 $\mathrm{min}-24 \mathrm{~h}$ ).

MTT assay. For the MTT colorimetric assay of cell survival, we used a method described by Kang et al (14) with minor modifications. Cell aliquots were seeded $\left(3 \times 10^{5}\right)$ in microplate wells and incubated with $20 \mu \mathrm{l}$ of an MTT solution $(5 \mathrm{mg} / \mathrm{ml})$ for $4 \mathrm{~h}$ at $37^{\circ} \mathrm{C}$ under $5 \% \mathrm{CO}_{2}$ and $95 \%$ air. This was followed by the addition of $100 \mu \mathrm{l}$ of DMSO in order to extract the MTT formazan. An automatic microplate reader (Molecular Devices, Sunnyvale, CA, USA) was used to read the absorbance of each well at $540 \mathrm{~nm}$.

Cytokine assay. The HMC-1 cells were pretreated with various concentrations of TET $(10-50 \mu \mathrm{M})$ for $1 \mathrm{~h}$ prior to PMA plus A23187 stimulation. Enzyme-linked immunosorbent assay (ELISA) was used to assay the culture supernatant for the TNF- $\alpha$, IL-6 and IL-8 protein levels. To measure the cytokine, a modified ELISA method was utilized. A sandwich ELISA was initially conducted for TNF- $\alpha$, IL-6 and IL- 8 in duplicate in 96-well ELISA plates (Nunc, Roskilde, Denmark). The supernatant was decanted into a new microcentrifuge tube and the cytokine were quantified by ELISA. ELISA plates (Falcon, Becton-Dickinson Labware, Franklin Lakes, NJ, USA) were coated overnight at $4^{\circ} \mathrm{C}$ with anti-human TNF- $\alpha$, IL- 6 and IL- 8 monoclonal antibodies diluted in coating buffer (0.1 M carbonate, $\mathrm{pH} 9.5)$ and then washed four times with phosphate-buffered saline (PBS) containing $0.05 \%$ Tween-20. The non-specific protein binding sites were blocked with assay diluent (PBS containing 10\% FBS, pH 7.0) for at least $1 \mathrm{~h}$. After washing the plates again, the test sample or recombinant TNF- $\alpha$, IL- 6 and IL- 8 standards were added. Following incubation for $2 \mathrm{~h}$, a working detector (biotinylated anti-human TNF- $\alpha$, IL-6 and IL-8, monoclonal antibodies and streptavidin-horseradish peroxidase reagent) was added and incubated for $1 \mathrm{~h}$. Accordingly, substrate solution (tetramethylbenzidine) was added to the wells and incubated for $30 \mathrm{~min}$ in the dark before the reaction was stopped with a solution of $1 \mathrm{M} \mathrm{H}_{3} \mathrm{PO}_{4}$. The absorbance was read at $450 \mathrm{~nm}$. All subsequent steps occurred at room temperature, and all standards and samples were assayed in duplicate.

Reverse transcriptase-polymerase chain reaction (RT-PCR) and quantitative RT-PCR analysis. Using a GeneAllR RiboEx RNA extraction kit (GeneAll Biotechnology, Republic of Korea), total RNA was isolated from HMC-1 cells according to the manufacturer's specifications. The concentration of total RNA in the final eluate was determined by spectrophotometry (Thermo Fischer Scientific Inc., Waltham, MA, USA). The total RNA $(2.0 \mu \mathrm{g})$ was heated at $65^{\circ} \mathrm{C}$ for $10 \mathrm{~min}$ and then cooled on ice. A cDNA synthesis kit (iNtRON Biotech, Republic of Korea) was used for $90 \mathrm{~min}$ at $37^{\circ} \mathrm{C}$ to reverse-transcribe each sample to cDNA. Primer sequences for TNF- $\alpha$, IL-6, IL-8, COX-2 and $\beta$-actin were used for PCR analysis as previously described (15). The PCR products increased as the concentration of RNA increased. The products were electrophoretically resolved on a $2.0 \%$ agarose gel and visualized by staining with ethidium bromide. The levels of TNF- $\alpha$, IL-6, IL- 8 and $\beta$-actin mRNA were measured with the real-time reverse transcription (RT)-PCR method using SYBR-Green. Total RNA was extracted from the cells with an RNeasy ${ }^{\circledR}$ Mini kit (Qiagen Inc., Valencia, CA, USA). Aliquots $(1 \mu \mathrm{g})$ of total RNA were used for RT, using a Prime Script ${ }^{\mathrm{TM}}$ RT reagent kit (Takara Bio, Inc.) and a Smart cycler ${ }^{\circledR}$ II System; Takara Bio, Inc.). The RT reaction was performed in a total volume of $20 \mu \mathrm{l}$ using a SYBR Premix Ex Taq (Takara Bio, Inc.), with $2 \mu \mathrm{l}$ of the cDNA sample being used as a template. The sequences are shown in Table I. Cycling was initiated with an activation step at $95^{\circ} \mathrm{C}$ for $10 \mathrm{sec}$, and an amplification program was repeated 45 times (denaturation, $95^{\circ} \mathrm{C}$ for $5 \mathrm{sec}$; annealing/extension, $60^{\circ} \mathrm{C}$ for $20 \mathrm{sec}$ ) with fluorescence measurement at $72^{\circ} \mathrm{C}$.

The fluorescence of the SYBR-Green dye was determined as a function of the PCR cycle number. In order to confirm amplification specificity, the PCR products from each primer pair were subjected to a melting curve analysis. The $\Delta \mathrm{CT}$ values $(\mathrm{Ct}=$ cycle threshold value) for the housekeeping gene $(\beta$-actin) and the target gene (TNF- $\alpha$, IL- 6 and IL-8) were calculated by subtracting the experiment group (PMA + A23187 + TET) from the control (non-stimulated value). The relative expression of the target gene was calculated on the basis of $2-\Delta(\Delta \mathrm{Ct})$. The $\Delta(\Delta \mathrm{Ct})$ values were calculated by subtracting the drug treated $(\mathrm{PMA}+\mathrm{A} 23187+\mathrm{TET}) \Delta \mathrm{Ct}$ from the control $(\mathrm{PMA}+\mathrm{A} 23187) \Delta \mathrm{Ct}$.

Preparation of cytoplasmic and nuclear extracts. Nuclear and cytoplasmic extracts were prepared as described 
Table I. Sequences of oligonucleotide primers designed for real-time PCR.

\begin{tabular}{llll}
\hline Genes & \multicolumn{1}{c}{ Forward (5'-3' orientation) } & Reverse (5'-3' orientation) & Accession no. \\
\hline hTNF- $\alpha$ & GACAAGCCTGTAGCCCATGTTGTA & CAGCCTTGGCCCTTGAAGA & NM 000594.2 \\
hIL-6 & AAGCCAGAGCTGTGCAGATGAGTA & TGTCCTGCAGCCACTGGTTC & NM 000600.1 \\
hIL-8 & ACACTGCGCCAACACAGAAATTA & TTTGCTTGAAGTTTCACTGGCATC & NM 00584.2 \\
$\beta$-actin & ATTGCCGACAGGATGCAGAAG & ATGGAGCCACCGATCCACA & NM 0016142 \\
\hline
\end{tabular}

The primers pairs were designed using Primer Express ${ }^{\circledR}$ software.

previously (14). Briefly, following activation of the cells for the time periods indicated, $5 \times 10^{6}$ cells were washed with ice-cold PBS and centrifuged at $15,000 \mathrm{x} \mathrm{g}$ for $1 \mathrm{~min}$. The cells were resuspended in $40 \mu \mathrm{l}$ of a cold hypotonic buffer [10 $\mathrm{mM}$ Hepes/ $\mathrm{KOH}, 2 \mathrm{mM} \mathrm{MgCl}$, $0.1 \mathrm{mM}$ EDTA, $10 \mathrm{mM} \mathrm{KCl,} 1 \mathrm{mM}$ DTT, and $0.5 \mathrm{mM}$ PMSF, $\mathrm{pH}$ 7.9]. The cells were allowed to swell on ice for $15 \mathrm{~min}$, followed by gentle lysis with $2.5 \mu \mathrm{l}$ of $10 \%$ Nonide P (NP)-40 and then centrifugation at 15,000 $\mathrm{x} g$ for 3 $\min$ at $4^{\circ} \mathrm{C}$. The supernatant was collected and used as the cytoplasmic extract. The nuclear pellets were gently resuspended in $40 \mu \mathrm{l}$ of cold saline buffer [50 mM HEPES/KOH, $50 \mathrm{mM} \mathrm{KCl}$, $300 \mathrm{mM} \mathrm{NaCl}, 0.1 \mathrm{mM}$ EDTA, 10\% glycerol, $1 \mathrm{mM}$ DTT, and $0.5 \mathrm{mM}$ PMSF, pH 7.9] and left on ice for $20 \mathrm{~min}$. Following centrifugation $\left(15,000 \mathrm{x} \mathrm{g}\right.$ for $15 \mathrm{~min}$ at $\left.4^{\circ} \mathrm{C}\right)$, the aliquots of the supernatant containing nuclear proteins were frozen in liquid nitrogen and stored at $-70^{\circ} \mathrm{C}$ until ready for analysis. The bicinchoninic acid protein assay (Sigma Chemical Co.) was used for protein quantification.

Western blot analysis. The HMC-1 cells $\left(5 \times 10^{6}\right.$ cells/well $)$ were stimulated with PMA $(50 \mathrm{nM})$ plus A23187 $(1 \mu \mathrm{M})$. Cell lysates were prepared in a sample buffer containing sodium dodecyl sulfate (SDS). The samples were heated at $95^{\circ} \mathrm{C}$ for $5 \mathrm{~min}$ and briefly cooled on ice. Following centrifugation at $15,000 \mathrm{x} \mathrm{g}$ for $5 \mathrm{~min}$, the proteins in the cell lysates were separated by $10 \%$ SDS-polyacrylamide gel electrophoresis (SDS-PAGE) and transferred to a nitrocellulose membrane. The membrane was then blocked with 5\% skim milk in PBS Tween-20 for $1 \mathrm{~h}$ at room temperature and then incubated with primary antibody. After washing the blot in PBS Tween-20 three times, it was incubated with a secondary antibody for $1 \mathrm{~h}$ and then the antibody-specific proteins were visualized using an enhanced chemiluminescence detection system as per the manufacturer's instructions (Amersham Corp., Newark, NJ, USA).

Statistical analysis. Statistical analysis was performed using one-way analysis of variance (ANOVA) followed by Dunnett's t-test for multiple comparisons, and the Student's test for single comparisons. The data from the experiments are presented as means \pm SEM. The number of independent experiments assessed are provided in the figure legends.

\section{Results}

Effects of TET on cytotoxicity in HMC-1 cells. The cytotoxicity of TET was evaluated using MTT assay, and TET was found not to affect HMC-1 cell viability at concentrations of 10 and

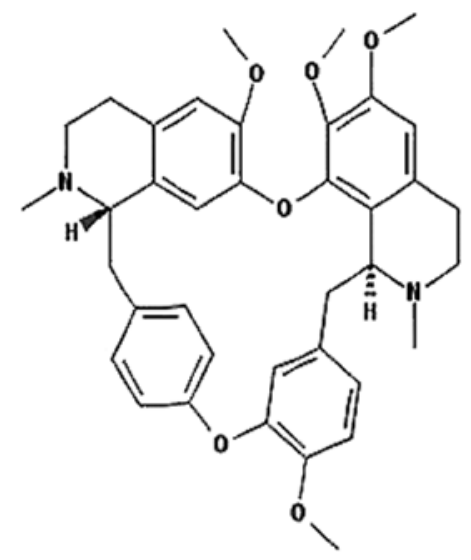

Figure 1. Chemical structure of TET.

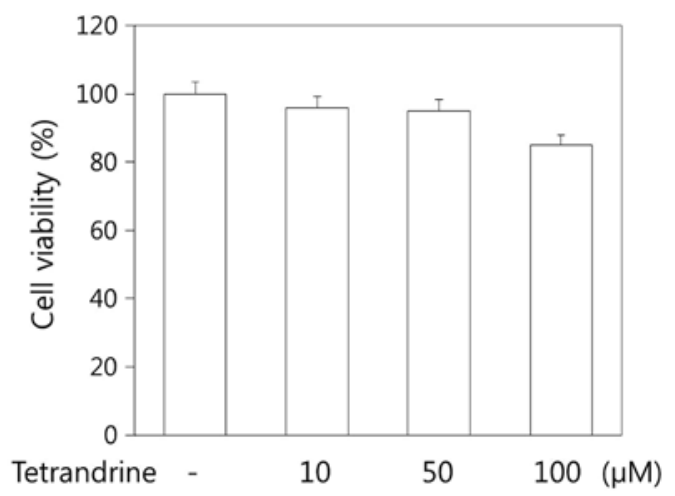

Figure 2. Effect of TET on cell viability in HMC-1 cells. Cell viability was evaluated with the MTT assay. Data are the means \pm SEM of duplicate determinations from three separate experiments.

$50 \mu \mathrm{M}$. However, the cytotoxicity of TET was evaluated to be at a high concentration of $100 \mu \mathrm{M}$ (Fig. 2).

Effects of TET on pro-inflammatory cytokine production. To evaluate the potential effects of TET on the production of proinflammatory cytokines, the cells were pretreated with TET (10 and $50 \mu \mathrm{M})$ prior to stimulation with PMA (50 $\mathrm{nM}$ ) and A23187 $(1 \mu \mathrm{M})$ for $8 \mathrm{~h}$, and further analysis using ELISA was carried out. As shown in Fig. 3, the levels of TNF- $\alpha$, IL-6, and IL-8 were considerably increased after stimulation with PMA plus A23187 in HMC-1. Pretreatment of cells with TET (10 and $50 \mu \mathrm{M})$ significantly inhibited the increase of these protein levels in a concentration-dependent manner. The 


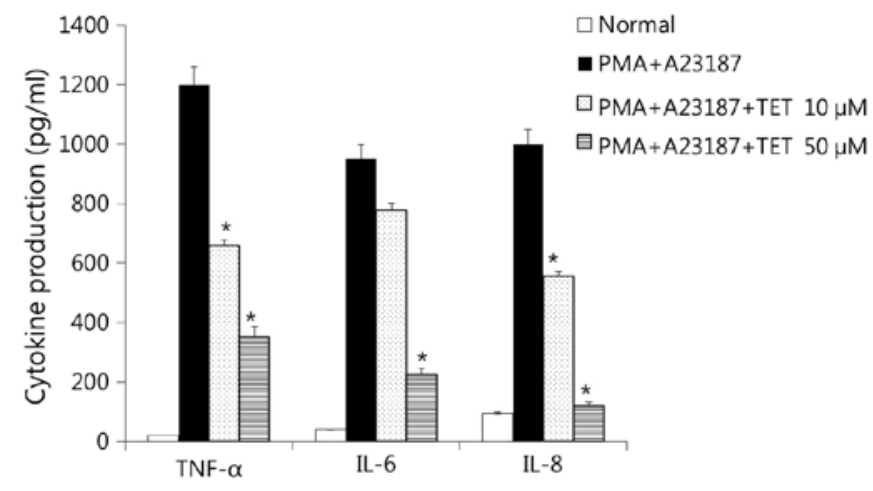

Figure 3. Effect of TET on the production of pro-inflammatory cytokines in PMA plus A23187-induced HMC-1 cells. HMC-1 cells were pretreated with TET $(10$ and $50 \mu \mathrm{M})$ for $1 \mathrm{~h}$ prior to PMA + A23187 stimulation. The levels of TNF- $\alpha$, IL- 6 and IL- 8 were determined by ELISA. Each bar is the mean \pm SEM of three independent experiments. ${ }^{*} \mathrm{P}<0.01$ compared to PMA+A23187-stimulated values.

maximal inhibition of TNF- $\alpha$, IL- 6 and IL- 8 production by TET $(50 \mu \mathrm{M})$ was $\sim 70,71$ and $88 \%$, respectively.

Effects of TET on pro-inflammatory cytokine gene expression . The pro-inflammatory cytokine gene expression was analyzed using RT-PCR and RT-qPCR. Enhanced TNF- $\alpha$, IL- 6 and IL-8 mRNA expression induced by PMA plus A23187 was inhibited by the pretreatment of the cells with TET (Fig. 4). In particular, pretreatment with TET at a concentration of 10 and $50 \mu \mathrm{M}$ inhibited the PMA and A23187-induced gene expression of TNF- $\alpha$, IL- 6 and IL-8.

Effects of TET on COX-2 protein and COX-2 mRNA expression. In recent studies, the important roles of COX-2 in mast cell-mediated inflammation have been demonstrated (16). Thus, to determine the effects of TET on COX-2 protein and COX-2 mRNA expression induced by PMA plus A23187, western blot and RT-PCR analysis were conducted. The cells were pretreated with TET $(10$ and $50 \mu \mathrm{M})$ for $1 \mathrm{~h}$ and then treated with PMA plus A23187. As shown in Fig. 5, TET inhibited the PMA plus A23187-induced COX-2 protein and COX-2 mRNA expression.

Effects of TET on activation of MAPKs. To evaluate the mechanisms underlying the effects of TET, we examined the potential effects of TET on activation of MAPKs. The stimulation of HMC-1 cells with PMA plus A23187 resulted in an increased phosphorylation of all three types of MAPKs, p38, JNK and ERK, after 15-30 min (data not shown). As shown in Fig. 6, TET attenuated PMA plus A23187-induced phosphorylation of ERK1/2 and JNK1/2, but did not affect the phosphorylation of p38 MAPK.

Effects of TET on NF- $\kappa B$ activation, I $\kappa$ B $\alpha$ phosphorylation and degradation. The expression of the pro-inflammatory cytokine tested in this study is known to be regulated by a transcription factor, NF- $\mathrm{BB}$ (17). Therefore, we examined whether TET affects the expression of NF- $\kappa \mathrm{B}$ signaling molecules or NF- $\mathrm{KB}$ transcriptional activity. To evaluate the mechanism of the effect of TET on the gene expression of
A
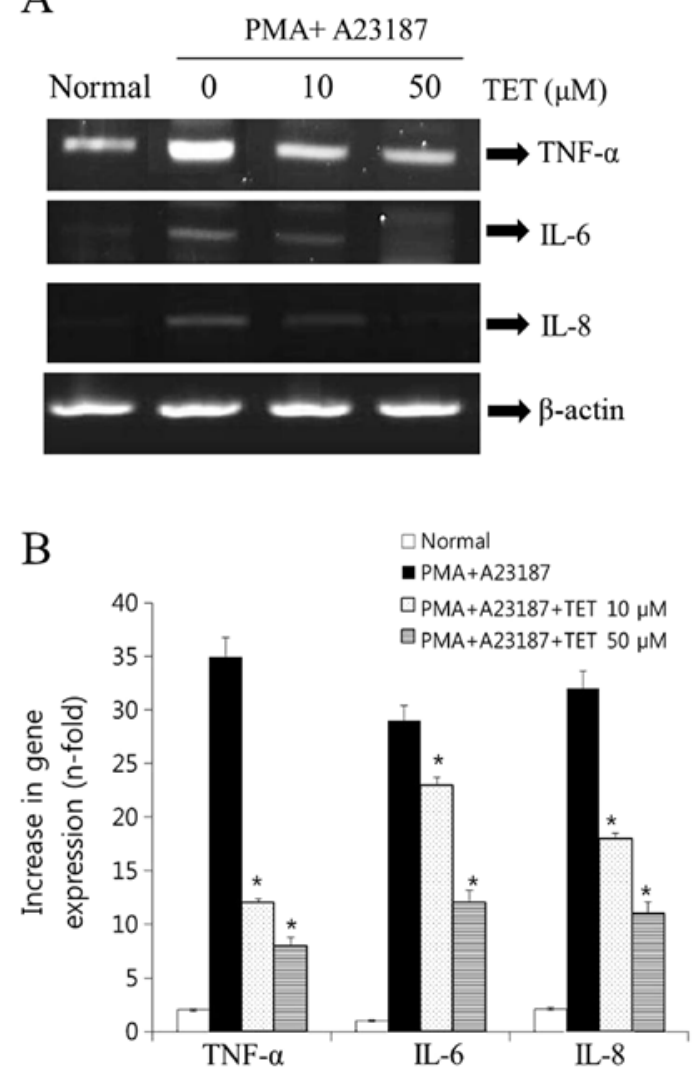

Figure 4. Effect of TET on the gene expression of pro-inflammatory cytokines in PMA plus A23187-induced HMC-1 cells. Cells were pretreated with TET $(10$ and $50 \mu \mathrm{M})$ for $1 \mathrm{~h}$ prior to PMA $(50 \mathrm{nM})+\mathrm{A} 23187(1 \mu \mathrm{M})$ stimulation for $6 \mathrm{~h}$. The mRNA expression level of TNF- $\alpha$, IL- 6 and IL-8 was determined by RT-PCR (A) and RT-qPCR (B). Each bar is the means \pm SEM of three independent experiments. ${ }^{*} \mathrm{P}<0.05$, compared with PMA+A23187-stimulated values.

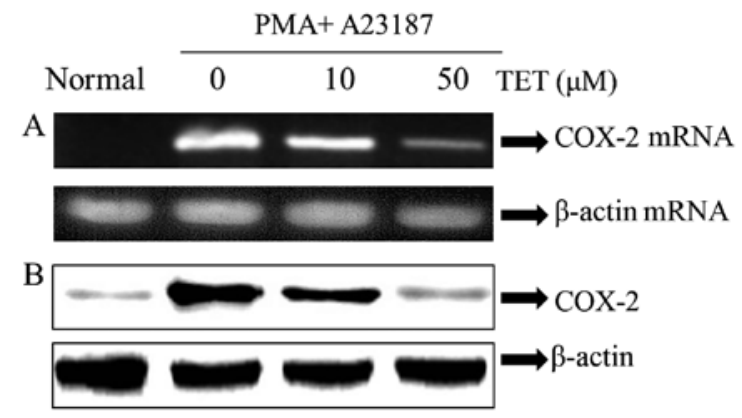

Figure 5. Effect of TET on COX-2 mRNA and COX-2 protein expression in PMA plus A23187-induced HMC-1 cells.(A) Cells were pretreated with TET for $1 \mathrm{~h}$ prior to PMA $(50 \mathrm{nM})+\mathrm{A} 23187(1 \mu \mathrm{M})$ stimulation for $10 \mathrm{~h}$, and then the expression of COX-2 mRNA was analyzed by RT-PCR. (B) Cells were pretreated with TET for $1 \mathrm{~h}$ prior to PMA $(50 \mathrm{nM})+\mathrm{A} 23187(1 \mu \mathrm{M})$ stimulation for $24 \mathrm{~h}$, and then the expression of the COX-2 protein was analyzed by western blot analysis.

pro-inflammatory cytokines, we examined the possible effects of TET on NF- $\kappa B$ activation. Stimulation of HMC-1 cells with PMA plus A23187 induced the degradation and phosphorylation of $I \kappa B \alpha$ and promoted the nuclear translocation of $\mathrm{p} 65$ NF- $\mathrm{KB}$ after $2 \mathrm{~h}$ of incubation (Fig. 7). As shown in Fig. 7, 


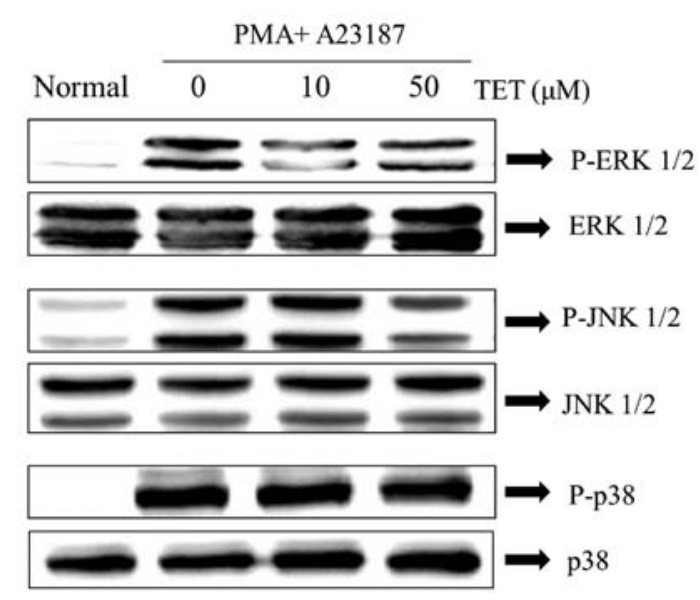

Figure 6. Effect of TET on PMA plus A23187-stimulated MAPKs activation. After pretreatment of TET for $1 \mathrm{~h}, \mathrm{HMC}-1$ cells were stimulated by PMA $(50 \mathrm{nM})$ and A23187 $(1 \mu \mathrm{M}) 30 \mathrm{~min}$ for MAPKs activation. Phosphorylation of ERK1/2, JNK1/2 and p38 MAPKs was analyzed by western blotting.

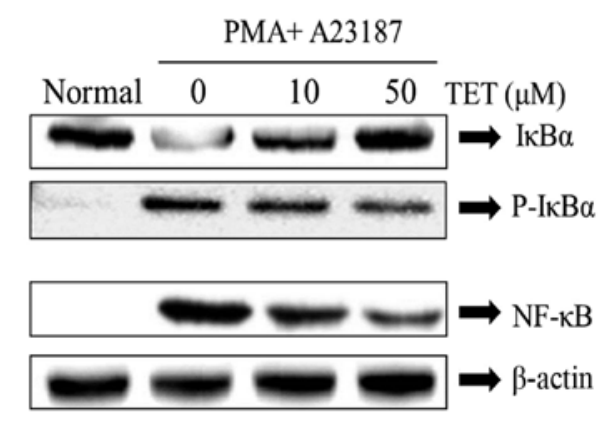

Figure 7. Effect of TET on PMA plus A23187-stimulated NF- $\kappa$ B activation, I $\mathrm{B} \alpha$ phosphorylation and degradation. HMC-1 cells were pretreated with TET for $1 \mathrm{~h}$ prior to PMA $(50 \mathrm{nM})$ and A23187 $(1 \mu \mathrm{M})$ stimulation. I $\mathrm{B} \alpha$ degradation, I $\kappa \mathrm{B} \alpha$ phosphorylation and $\mathrm{NF}-\kappa \mathrm{B}$ translocation were assayed by western blotting.

TET inhibited the PMA plus A23187-induced degradation and phosphorylation of $\mathrm{I} \kappa \mathrm{B} \alpha$ as well as the nuclear translocation of p65 NF-кB.

\section{Discussion}

Several studies have previously demonstrated anti-inflammatory effects of novel compounds by the modulation of mast cell activation (16). Natural product-based compounds seem better than synthetic compounds since natural product-based compounds are generally devoid of severe side-effects (18). Bis-benzylisoquinoline alkaloid, such as TET, has antiinflammatory, immunologic and antiallergenic effects. It has a 'Quinidine-like' anti-arrhythmic effect. It has been isolated from Stephania tetrandra S Moore, and other Chinese and Japanese herbs (19). Previous studies have reported that TET has vasodilatory properties and can therefore reduce blood pressure (20). Moreover, TET has potential therapeutic value to prevent excess scarring/fibrosis in conjunctiva following trabeculectomy or in patients with severe conjunctival inflammation (21). However, the activity of TET on PMA plus A23187-stimulated mast cell activation has not been well investigated. Therefore, in the present study, we inves- tigated whether TET exerts a therapeutic effect on allergic inflammatory disease.

Mast cell-derived pro-inflammatory cytokine, particularly TNF- $\alpha$, IL- 6 and IL- 8 have a critical biological role in allergic inflammation. Inflammatory cytokines are important factors in chronic inflammation, allergy, asthma, atherogenesis and autoimmune diseases. Human mast cells play an integral role in the inflammatory response by accumulating at sites of inflammation and mediating the production of inflammatory cytokines, such as IL-6 and IL-8 (22). Previous studies have indicated that the reduction of pro-inflammatory cytokine from mast cells is one of the key indicators of reduced inflammatory symptoms (16). The aim of the present study was to examine the effects of TET on the production of TNF- $\alpha$, IL-6 and IL- 8 in HMC-1 cells, as these cytokines have powerful inflammatory effects and are released by activated mast cells. The results showed that TET inhibits TNF- $\alpha$, IL- 6 and IL-8 production in PMA plus A23187-activated mast cells (Fig. 3). Moreover, RT-PCR and RT-qPCR analysis of the gene expression of the inflammatory cytokines, TNF- $\alpha$, IL-6 and IL-8, revelaed inhibitory effects in PMA plus A23187-stimulated HMC-1 (Fig. 4). TET blocked COX-2 activation in a dose-dependent manner (Fig. 5). Therefore, these results showed that TET exerts markedly anti-inflammatory effects in PMA plus A23187-stimulated HMC-1.

We investigated whether MAPK activation recognizes the mechanism involved in the effect of TET on pro-inflammatory cytokine expression in HMC-1 cells. In mammals, three major factors that mediate the MAPK pathways have been identified: ERKs, p38 and stress-activated protein kinases (SAPKs)/JNK (23). ERKs, p38 and JNK are activated in response to different extracellular stimuli, in that they have different downstream targets and therefore perform different functions, including mediation of apoptosis, proliferation and inflammation (24). The effect of TET on the activation of MAPK members in selected cell lines has also been reported. In previous studies, TET was shown to inhibit IgE-mediated activation of ERK and JNK but not of p38 MAPK in human cultured mast cells (25). It was also shown to inhibit the phosphorylation of ERK1/2 and p38 but not of JNK1/2, in LPS-induced macrophages (26). This discrepancy may arise from differences in stimulation or the cell type. Results of the present study demonstrated that, the activities of MAP kinases were increased by PMA plus A23187, and TET significantly restored the phosphorylation of ERK and JNK but not of p38 MAPK (Fig. 6). These results suggest that TET inhibited proinflammatory cytokine production via the inhibition of ERK and JNK activation.

Since suppression of NF- $\kappa \mathrm{B}$ activation has been associated with anti-inflammation, we hypothesized that TET mediated its effects at least partly through the suppression of $\mathrm{NF}-\kappa \mathrm{B}$ activation. Activation of $\mathrm{NF}-\kappa \mathrm{B}$ is dependent on the degradation of $\mathrm{I} \kappa \mathrm{B} \alpha$, an endogenous inhibitor that binds to NF- $\kappa \mathrm{B}$ in the cytoplasm. The role of $\mathrm{NF}-\kappa \mathrm{B}$ activation and its regulation of cytokine production in inflammation have already been characterized (27). Expression of the TNF- $\alpha$, IL-6 and IL-8 genes is dependent on the activation of transcription factor $\mathrm{NF}-\kappa \mathrm{B}$ in mast cells. Previous studies have reported that the activation of NF- $\kappa \mathrm{B}$ increased the expression of COX-2 (15). This suggests that TET inhibits COX-2 expression through 
the suppression of NF- $\kappa \mathrm{B}$ activation in HMC-1. In PMA and A23187-stimulated mast cells, TET decreased the degradation and phospholylation of $\mathrm{I} \kappa \mathrm{B} \alpha$, and inhibited the nuclear translocation of $\mathrm{p} 65 \mathrm{NF}-\kappa \mathrm{B}$. Therefore, this demonstrated that TET inhibited the PMA and A23187-induced TNF- $\alpha$, IL-6, IL-8 and $\mathrm{COX}-2$ expression via the attenuation of NF- $\mathrm{KB}$ activation. Future studies to confirm the results of the present study, as well as to elucidate the molecular mechanism of action of TET, are currently underway in our laboratory.

In conclusion, TET regulated the production of TNF- $\alpha$, IL-6, IL-8 in PMA plus A23187-stimulated HMC-1 cells. TET also decreased COX-2 expression. Furthermore, TET inhibited the ERK1/2, JNK1/2 and NF- $\mathrm{B}$ pathways. Therefore, the regulation of the NF- $\kappa \mathrm{B}$ signaling pathway by TET in HMC-1 cells is a potentially attractive and characteristic probe for studying mast cell-mediated allergic diseases.

\section{Acknowledgements}

This study was supported by the Basic Science Research Program through the National Research Foundation of Korea (NRF) funded by the Ministry of Science, ICT and Future Planning (NRF-2011-0014996) and by the Korean government (MSIP) (2008-0062484), and by the Ministry of Education (2013060380), and by the Traditional Korean Medicine R\&D Project, Ministry of Health and Welfare (No. B120069), Republic of Korea.

\section{References}

1. Pang L and Hoult JR: Cytotoxicity to macrophages of tetrandrine, an antisilicosis alkaloid, accompanied by an overproduction of prostaglandins. Biochem Pharmacol 53: 773-782, 1997.

2. Mashour NH, Lin GI and Frishman WH: Herbal medicine for the treatment of cardiovascular disease: clinical considerations. Arch Intern Med 158: 2225-2234, 1998.

3. Yu XF, Zou CQ and Lin MB: Observation of the effect of tetrandrine on experimental silicosis of rats. Ecotoxicol Environ Saf 7: 306-312, 1983.

4. Ho LJ and Lai JH: Chinese herbs as immunomodulators and potential disease-modifying antirheumatic drugs in autoimmune disorders. Curr Drug Metab 5: 181-192, 2004.

5. Kim HS, Zhang YH and Yun YP: Effects of tetrandrine and fangchinoline on experimental thrombosis in mice and human platelet aggregation. Planta Medica 65: 135-138, 1999.

6. Lee JH, Kang GH, Kim KC, Kim KM, Park DI, Choi BT, Kang HS, Lee YT and Choi YH: Tetrandrine-induced cell cycle arrest and apoptosis in A549 human lung carcinoma cells. Int J Oncol 6: 1239-1244, 2002.

7. Zhu Z, Homer RJ, Wang Z, Chen Q, Geba GP, Wang J, Zhang Y and Elias JA: Pulmonary expression of interleukin-13 causes inflammation, mucus hypersecretion, subepithelial fibrosis, physiologic abnormalities, and eotaxin production. J Clin Invest 103: 779-788, 1999.

8. Barnes PJ and Adcock I: Anti-inflammatory actions of steroids: molecular mechanisms. Trends. Pharmacol Sci 14: 436-441, 1993.

9. Pastore S, Fanales-Belasio E, Albanesi C, Chinni LM, Giannetti A and Girolomoni G: Granulocyte macrophage colony-stimulating factor is overproduced by keratinocytes in atopic dermatitis. Implications for sustained dendritic cell activation in the skin. J Clin Invest 99: 3009-3017, 1997.

10. Newton R, Kuitert LM, Bergmann M, Adcock IM and Barnes PJ: Evidence for involvement of NF-kappaB in the transcriptional control of COX-2 gene expression by IL-1beta. Biochem Biophys Res Commun 237: 28-32, 1997.
11. Hirasawa N, Santini F and Beaven MA: Activation of the mitogen-activated protein kinase/cytosolic phospholipase A2 pathway in a rat mast cell line. Indications of different pathways for release of arachidonic acid and secretory granules. J Immunol 154: 5391-5402, 1995.

12. McDaniel AS, Allen JD, Park SJ, Jaffer ZM, Michels EG, Burgin SJ, Chen S, Bessler WK, Hofmann C, Ingram DA, Chernoff $\mathbf{J}$ and Clapp DW: Pak1 regulates multiple c-Kit mediated Ras-MAPK gain-in-function phenotypes in $\mathrm{Nf} 1+/-$ mast cells. Blood 112: 4646-4654, 2008.

13. Moller C, Alfredsson J, Engström M, Wootz H, Xiang Z, Lennartsson J, Jönsson JI and Nilsson G: Stem cell factor promotes mast cell survival via inactivation of FOXO3a-mediated transcriptional induction and MEK-regulated phosphorylation of the proapoptotic protein Bim. Blood 106: 1330-1336, 2005.

14. Kang OH, Lee GH, Choi HJ, Park PS, Chae HS and Jeong SI: Ethyl acetate extract from Angelica Dahuricae Radix inhibits lipopolysaccharide-induced production of nitric oxide, prostaglandin E2 and tumor necrosis factor-alpha via mitogen-activated protein kinases and nuclear factor-kappaB in macrophages. Pharmacol Res 55: 263-270, 2007.

15. Bochenek G, Nizankowska E, Gielicz A, Swierczyńska M and Szczeklik A: Plasma 9alpha, 11beta-PGF , a PGD metabolite, as a sensitive marker of mast cell activation by allergen in bronchial asthma. Thorax 59: 459-464, 2004.

16. Kang OH, Choi JG, Lee JH and Kwon DY: Luteolin isolated from the flowers of Lonicera japonica suppresses inflammatory mediator release by blocking NF-kappaB and MAPKs activation pathways in HMC-1 cells. Molecules 15:385-398, 2010.

17. Azzolina A, Bongiovanni A and Lampiasi N: Substance P induces TNF-alpha and IL-6 production through NF kappa B in peritoneal mast cells. Biochim Biophys Acta 1643: 75-83, 2003.

18. Kuprsh DV, Udalova IA, Turetskaya RL, Rice NR and Nedospasov SA: Conserved kappa B element located downstream of the tumor necrosis factor alpha gene: distinct NF-kappa B binding pattern and enhancer activity in LPS activated murine macrophages. Oncogene 11: 97-106, 1995.

19. Zhang L, Geng Y, Duan W, Wang D, Fu M and Wang X: Ionic liquid-based ultrasound-assisted extraction of fangchinoline and tetrandrine from Stephaniae tetrandrae. J Sep Sci 32: 3550-3554, 2009.

20. Kwan CY and Achike FI: Tetrandrine and related bis-benzylisoquinoline alkaloids from medicinal herbs: cardiovascular effects and mechanisms of action. Acta Pharmacol Sin 23: 1057-1068, 2002.

21. Kitano A, Yamanaka O, Ikeda K, Ishida-Nishikawa I, Okada Y, Shirai K and Saika S: Tetrandrine suppresses activation of human subconjunctival fibroblasts in vitro. Curr Eye Res 33: 559-565, 2008.

22. Henz BM, Maurer M, Lippert U, Worm M and Babina M: Mast cells as initiators of immunity and host defense. Exp Dermatol 10: 1-10, 2001.

23. Widmann C, Gibson S, Jarpe MB and Johnson GL: Mitogenactivated protein kinase: conservation of a three-kinase module from yeast to human. Physiol Rev 79: 143-180, 1999.

24. Yamamoto Y, Yin MJ, Lin KM and Gaynor RB: Gaynor Sulindac inhibits activation of the NF-kappaB pathway. J Biol Chem 274: 27307-27314, 1999.

25. Kimata M, Shichijo M, Miura T, Serizawa I, Inagaki N and Nagai H: Effects of luteolin, quercetin and baicalein on immunoglobulin E-mediated mediator release from human cultured mast cells. Clin Exp Allergy 30: 501-508, 2000.

26. Xagorari A, Roussos C and Papapetropoulos A: Inhibition of LPS-stimulated pathways in macrophages by the flavonoid luteolin. Br J Pharmacol 136: 1058-1564, 2002.

27. Blackwell TS, Blackwell TR and Christman JW: Impaired activation of nuclear factor-kappaB in endotoxin-tolerant rats is associated with down-regulation of chemokine gene expression and inhibition of neutrophilic lung inflammation. J Immunol 158: 5934-5940, 1997. 